\title{
Analisis Model Pembelajaran Hipotesis Deduktif Terhadap Pemahaman Konsep Siswa pada Materi Gerak Harmonik Sederhana
}

\author{
Anggiani Anggiani ${ }^{1, \text { a) }}$ Nana $^{2, b)}$ \\ Program Studi Pendidikan Fisika, Universitas Siliwangi \\ Email: ${ }^{\text {a)} 182153059 @ ~ @ s t u d e n t . u n s i l . a c . i d, ~}{ }^{b}$ nana@ @nsil.ac.id
}

\begin{abstract}
This study aims to analyze the physics learning process with a deductive hypothesis learning model on students' understanding of concepts in simple harmonic motion material. The method used in this study is a literature study by reviewing some of the literature to be analyzed and concluded.
\end{abstract}

Keywords: Deductive Hypothesis Learning Model, Concept Understanding, Simple Harmonic Motion

\begin{abstract}
Abstrak
Penelitian ini berjutuan untuk menganalisis proses pembelajaran fisika dengan dengan model pembelajaran hipotesis deduktif terhadap pemahaman konsep siswa pada materi gerak harmonik sederhana. Metode yang digunakan dalam penelitian ini yaitu dengan studi kepustakaan dengan mengkaji beberapa literatur untuk dianalisis dan dibuat kesimpulan.
\end{abstract}

Kata-kata kunci: Model Pembelajaran Hipotesis Deduktif, Pemahaman Konsep, Gerak Harmonik Sederhana.

\section{PENDAHULUAN}

Fisika merupakan salah satu cabang ilmu dari rumpun Ilmu Pengetahuan Alam (IPA) yang mana di dalamnya mempelajari tentang fenomena alam. Kegiatan pembelajaran dalam fisika meliputi: mengamati, mengolah, menganalisis, dan menarik kesimpulan, yang bertujuan untuk meningkatkan keterampilan dasar bagi siswa sehingga dapat memahami suatu konsep yang telah ada atau proses penemuan suatu konsep baru. Dalam Peraturan Menteri Pendidikan Nasional (Permendiknas) nomor 41 tahun 2007 tentang standar proses kegiatan pembelajaran disebutkan bahwa proses pembelajaran pada setiap satuan pendidikan dasar dan menengah harus interaktif, inspiratif, menyenangkan, menantang, dan memotivasi peserta didik untuk berpartisipasi aktif, serta memberikan ruang yang cukup bagi prakarsa, dan kemandirian sesuai dengan bakat, minat, dan perkembangan fisik serta psikologis peserta didik. Hal tersebut menunjukkan bahwa pada saat kegiatan pembelajaran berlangsung peserta didik harus berperan aktif dalam proses pemebelajaran, yang mana harus ada interaksi aktif antara peserta didik dan guru.

Pada proses pembelajaran fisika di kelas, harus ada interaksi anatara guru dan peserta didik berupa pemberian stimus atau respon terhadap siswa ataupun sebaliknya. Interaksi efektif dalam pembelajaran mampu menyediakan stimulus belajar dan mengaktifkan respon pembelajaran sehingga respon antara guru dan siswa sangat dibutuhkan (Saputra, 2019). Pembelajaran fisika tentunya harus ada stimulus 
dan respon yang diberikan oleh guru maupun siswa itu sendiri, untuk mempermudah siswa dalam memahami konsep materi fisiska yang sedang dipelajari. Fisika merupakan salah satu mata pelajaran yang membutuhkan pemahaman konsep secara mendalam. Namun, kebanyakan siswa mendapatkan kesulitan dalam memahami konsep fisika.

Kesulitan peserta didik dalam memahami konsep terjadi karena proses pembelajaran yang kurang efektif dan model pembelajaran yang terkesan monoton (membosankan). Proses pembelajaran yang berfokus pada buku mata pelajaran, sehingga guru hanya memberikan referensi dari buku pelajaran atau memberikan materi melalui Power Point (PPT) saja membuat siswa kesulitan dalam pemahaman konsep materi yang sedang dipelajari. Oleh karena itu, dibutuhkan model pembelajaran yang menekankan pada pemahaman konsep siswa yaitu model pembelajaran hipotesis deduktif sebagai inovasi dalam pembelajaran. Inovasi pembelajaran sebagai perubahan yang baru dalam meningkatkan kemampuan demi mencapai tujuan tertentu berupa praktik-praktik pendidikan (Nana, 2018). Model siklus belajar hipotesis deduktif memiliki tiga tahapan dalam pembelajarannya yaitu, eksplorasi, pengenalan konsep, dan aplikasi konsep (Sari, Supriyanti, \& Dwiyanti, 2019).

Berdasarkan hasil penelitian sebelumnya mengenai model pembelajaran hipotesis deduktif memberikan dampak positif bagi pembelajaran fisika seperti penelitian yang telah dilakukan oleh Adnyana (2012) yang menyatakan bahwa model siklus belajar hipotetis deduktif dapat meningkatkan kualitas pembelajaran sehingga berpengaruh terhadap peningkatan keterampilan berpikir kritis dan pemahaman konsep siswa. Pada penelitian yang dilakukan oleh Muslimin, Yoga, \& Darmadi (2020) menunjukkan adanya pengaruh positif dari penerapan model pembelajaran hipotesis deduktif terhadap keterampilan generik sains siswa yang lebih baik dibandingkan dengan pembelajaran langsung (konvensional). Selanjutnya oleh Sudana (2020) model Pembelajaran Siklus Belajar HipotetikDeduktif telah terbukti efektif meningkatkan aktivitas dan hasil belajar siswa sesuai dengan Kurikulum 2013. Berdasarkan hasil penelitian sebelumya, ternyata model hipotesis deduktif berpengaruh terhadap hasil belajar dan pemahaman konsep siswa.

Pemahaman konsep dalam proses pembelajaran fisika tentunya menjadi salah satu hal penting dalam mempelajari materi fisika di sekolah. Salah satu mata pelajaran fisika SMA yang harus membutuhkan pemahaman konsep yaitu materi gerak harmonik sederhana. Beberapa peneliti telah mengungkapkan bahwa siswa mengalami kesulitan dalam memahami konsep gerak harmonik sedehana. Maharani, (2017: 5) mengemukakan bahwa proses pembelajaran fisika pada materi gerak harmonik sederhana ditemukan indikator pemahaman konsep yang masih rendah bahkan banyak terjadi miskonsepsi oleh para siswa. Menurut Husniyah, dkk (2016: 36) mayoritas siswa kesulitan dalam memecahkan masalah yang disajikan karena siswa belum bisa mengaitkan konsep yang telah dipelajari dalam gerak harmonis sederhana. Parnafes, 2010 (dalam Sugara, 2016: 506) menyebutkan pada materi gerak harmonik sederhana siswa kesulitan dalam menentukan perubahan arah dari benda yang berosilasi dan memaknai suatu grafik osilator. Dari permasalahn tersebut, maka materi gerak harmonik sederhana merupakan bahasan yang cocok dalam menerapkan model hipotesis deduktif untuk meningkatkan pemahaman konsep. Oleh karena itu, proses pembelajaran dengan menggunakan model hipotesis deduktif berpengaruh terhadap pemahaman konsep siswa pada materi gerak harmonik sederhana.

\section{METODE}

Metode yang digunakan untuk menganalisis proses pembelajaran melalui model pembelajaran hipotesis terhadap pemahaman konsep siswa pada materi gerak harmonik sederhana yaitu dengan studi kepustakaan. Data dikumpulkan dengan mengkaji beberapa literatur untuk dianalisis kemudian disajikan dalam hasil dan pembahasan agar dapat dibuat kesimpulan.

\section{HASIL DAN PEMBAHASAN}

\section{Model Pembelajaran Hipotesis Deduktif}

Model pembelajaran hipotesis deduktif merupakan suatu model pembelajaran yang berbasis konstruktivisme yang bersifat student centered yang menyajikan beberapa fenomena melalui 
pemberian stimulus respon oleh guru ataupun peserta didik sendiri. Stimulus berupa pembelajaran yang diramu dengan mengikuti langkah-langkah model siklus belajar hipotesis deduktif, secara teori mampu memberikanrespon positif terhadap proses pembelajaran yang dialakukan (Saputra, 2019).

Adapun langkah-langkah pembelajaran menggunakan model hipotesis deduktif adalah sebagai berikut, (1) pengajuan stimulus berupa suatu pertanyaan, (2) siswa diminta untuk merumuskan jawaban-jawaban (hipotesis-hipotesis) yang mungkin terhadap pertanyaan itu, (3) siswa diminta untuk menurunkan konsekuensi-konsekuensi logis dari hipotesis-hipotesis. (4) merencanakan serta melakukan eksperimen untuk menguji hipotesis-hipotesis itu (eksplorasi (5) menganalisis hasil eksperimen, (6) pengaplikasisan konsep (Sudana, 2020).

\section{Pemahaman Konsep}

Menurut Indriajati (2016: 17) pemahaman konsep adalah suatu tingkatan dimana siswa dapat menangkap makna suatu konsep baik yang berupa tulisan maupun verbal sehingga menghasilkan perubahan perilaku. Konsep dapat diartikan sebagai sebuah data yang dapat membantu seseorang dalam membuat keputusan dan bertindak. Konsep fisika terbentuk sebagai hasil dari abstraksi dan generalisasi yang berasal dari suatu pengamatan. Jadi pemahaman konsep siswa adalah cara siswa memahami suatu konsep pelajaran yang ada di sekolah melalui apa yang di ucapakan, ditulis, dicontohkan dan digambar oleh guru atau dengan menemukan konsep sendiri sesuai dengan pemikiran siswa. Pada kegiatan belajar, peserta didik tentunya harus dapat memahami suatu konsep dari mata pelajaran yang akan dipelajari. Pemahaman konsep tersebut nantinya menjadi bekal awal untuk dapat mempelajari materi yang lebih kompleks lagi, peserta didik secara aktif menemukan suatu konsep melalui pengamatan atau eksperimen secara langsung, bukan dari menghafal buku materi maupun penjelasan dari guru (Nana \& Surahman, 2019).

Pada materi gerak harmonik sederhana melalui melalui model pembelajaran hipotesisi deduktif terhadap pemahaman konsep siswa diukur melalui indikator: 1) Mengamati apa yang dijelaskan oleh guru; 2) Menjelaskan konsep gerak harmonik sederhana melalui pendapat siswa sendiri 3) Mengajukan pertanyaan terhadap apa yang disajikan 4) Mengklarifikasi konsep yang telah diteliti atau setelah percobaan 5) melakukan percobaan untuk merepresentasikan suatu konsep 6) Mengkomunikasikan hasil percobaan melalui presentasi di depan kelas 7) Mengevaluasi hasil kerja siswa melalui tes tulis.

\section{Materi Gerak Harmonik Sederhana}

Materi gerak harmonik sederhana pada pegas meliputi besaran gerak harmonik pada pegas, hubungan massa beban terhadap besar periode dan frekuensi pada pegas, dan hubungan konstanta pegas terhadap besar periode dan frekuensi pada pegas. Menurut permendikbud tahun 2016 nomor 24 materi gerak harmonik sederhana terdapat pada materi kelas X IPA. Kompetensi dasar materi tersebut terdapat pada KD 3.11 yakni: Menganalisis hubungan antara gaya dan getaran dalam kehidupan seharihari dan KD 4.11 yakni: Melakukan percobaan getaran harmonis pada ayunan sederhana dan/atau getaran pegas berikut presentasi hasil percobaan serta makna fisisnya.

\section{Analisis Model Pembelajaran Hipotesis Deduktif Terhadap Pemahaman Konsep Siswa pada Materi Gerak Harmonik Sederhana}

Pada proses pembelajaran fisika, banyak siswa yang kurang memahami suatu konsep dalam materi gerak harmonik sederhana. Materi gerak harmonik sederhana terkesan abstrak untuk dipahami oleh karena itu dibutuhkan model pemelajaran yang sesuai dan efektif supaya siswa dapat memahami konsepnya. Melalui model pembelajaran hipotesiis deduktif, proses pembelajaran siswa menjadi lebih bermakna dan dapat memahami konsep listrik searah dengan baik.

Penelitian sebelumnya yang dilakukan oleh Andani, Prastowo, dan Supeno (2018) dalam seminar nasional quantum yang berjudul "Identifikasi kemampuan penalaran hipotesis-deduktif siswa SMA dalam pembelajaran fisika materi hukum newton" menyatakan bahwa kemampuan hipotesis-deduktif siswa termasuk dalam kategori baik pada aspek kemampuan merumuskan hipotesis dengan persentase sebesar $83,59 \%$ dan capaian paling rendah adalah pada aspek kemampuan menyimpulkan kesimpulan 
berdasarkan teori dengan presentase $44,53 \%$. Hasil tersebut dipengaruhi proses pembelajaran, pengalaman dan latihan siswa, pemahaman konsep dan antusias siswa saat mengerjakan tes.

Pada penelitian Muslimin, Yoga, dan Darmadi (2020) "Pengaruh Model Siklus Belajar Hipotetikal Deduktif terhadap Keterampilan Generik Sains Siswa Kelas X di SMA Negeri 1 Balaesang pada Mate Pelajaran Fisika" menunjukkan bahwa adanya pengaruh positif dari penerapan model pembelajaran hipotesis deduktif terhadap keterampilan generik sains siswa yang lebih baik dibandingkan dengan pembelajaran langsung (konvensional), pada kelas eksperimen rata-rata $\mathrm{N}$-gain-nya 0,28 dan untuk kelas kontrol 0,21 sehingga kelas eksperimen lenih baik daripada kelas kontrol.

Penelitian lain dilakukan oleh Saputra (2019) dengan judul penelitian "Analisis Respon Guru dan Sisiwa Terhadap Penerapan Model Siklus Belajar Hipotesis Dedutif" pada jurnal pedagogik menyimpulkan bahwa guru dan siswa memberikan tanggapan positif terhadap penerapan model siklus belajar hipotesis deduktif dalam pembelajaran kesetimbangan kimia dilihat dari skor rerata tanggapan guru yang diperoleh melalui angket yang terkategori baik sekali, rerata skor tanggapan siswa sebesar 36,63 .

Sudana (2020) juga menyimpulkan pada penelitian yang telah dilakukannya yaitu Model Pembelajaran Siklus Belajar Hipotetik-Deduktif telah terbukti efektif meningkatkan aktivitas dan hasil belajar siswa sesuai dengan pendekatan saintifik, peneletian tersebut dilakukan melalui dua siklus yaitu siklus I rerata hasil ulangan harian sudah melampaui target sebesar 77,50; ketuntasan klasikal (KK) baru mencapai $83,33 \%$ (dari 36 orang siswa, jumlah siswa yang mencapai KKM hanya 30 orang, sedangkan 6 orang lainnya belum mencapai KKM), sehingga belum mencapai 85\%dan siklus II didapatkan rerata hasil ulangan harian telah mencapai 79,50 telah di atas target 76, ketuntasan klasikal (KK) sudah mencapai $88,89 \%$ telah melampaui target $85 \%$, dan aktivitas siswa telah meningkat tergolong aktif.

Selanjutnya penelitian juga dilakukan oleh Sari, Supriyanti, dan Dwiyanti (2019) dalam jurnal EduChemia Jurnal Kimia dan Pendidikan dengan judul "Analisis Keterampilan Proses Sains Pembelajaran Larutan Penyangga Menggunakan Siklus Belajar Hipotesis Deduktif” didapatkan bahwa keterampilan proses sains siswa untuk keterampilan mengamati, mengklasifikasikan, merencanakan percobaan tergolong dalam kriteria sangat baik, sedangkan mengajukan pertanyaan, mengajukan hipotesis, meramalkan, menggunakan alat dan bahan, menafsirkan pengamatan, menerapkan konsep, dan berkomunikasi tergolong dalam kategori baik. Keterampilan Proses Sains untuk masingmasing kategori siswa adalah (1) siswa kategori kelompok tinggi dapat mengembangkan 10 indikator KPS yang tergolong dalam kriteria sangat baik, (2) siswa kategori kelompok sedang dapat mengembangkan 10 indikator KPS yang tergolong dalam kriteria baik, (3) Siswa kategori kelompok rendah dapat mengembangkan 10 indikator KPS yang tergolong dalam kriteria baik (Sari, Supriyanti, \& Dwiyanti, 2019).

Berdasarkan hasil dan pembahasan studi literatur ini maka model pembeljaran hipotesis deduktif dapat diterapkan pada pembelajaran fisika. Pada penelitian selanjutnya setelah mengkaji literatur dari penelitian-penelitian sebelumnya, akan dilakukan penelitian dengan menggunakan model hipotesis deduktif pada meteri gerak harmonik sederhana terhadap pemahaman konsep siswa. Dengan menggunakan indikator mengamati, menjelaskan, mengklarifikasi, melakukan percobaan, mengkomunikasikan, dan mengevaluasi pada meteri gerak harmonik sederhana dapat mengetahui penggunaan pendekatan multirepresentasi terhadap pemahaman konsep siswa.

\section{KESIMPULAN}

Model pembeljaran hipotesis deduktif dapat digunakan dalam proses pembelajaran fisika terhadap pemahaman konsep siswa pada materi gerak harmonik. Selain itu, berdasarkan hasil dan pembahasan studi pustaka maka dapat disimpulkan bahwa model pembeljaran hipotesis deduktif secara signifikan dapat meningkatkan pemahaman konsep siswa SMA pada materi gerak harmonik sederhana. 


\section{UCAPAN TERIMAKASIH}

Terima kasih kepada semua pihak yang telah membantu demi kesempurnaan artikel ini menjadi lebih baik, khusus kepada Bapak Dr. Nana, M.Pd. selaku dosen mata kuliah Inovasi Pembelajaran Fisika dan Kepada teman-teman yang telah memberi semangat dan motivasi. 


\section{REFERENSI}

Adnyana, G. P. (2012). Keterampilan Berpikir Kritis dan Pemahaman Konsep Siswa Pada Model Siklus Belajar Hipotesis Deduktif. Jurnal Pendidikan dan Pengajaran, 3, 201-109.

Andani, I. D., Prastowo, S., \& Supeno. (2018). Identifikasi kemampuan penalaran hipotesis-deduktif siswa SMA dalam pembelajaran fisika materi hukum newton. Seminar Nasional Quantum, 24771511.

Muslimin, Yoga, W., \& Darmadi, W. (2020). Pengaruh Model Siklus Belajar Hipotetikal Deduktif terhadap Keterampilan Generik Sains Siswa Kelas X di SMA Negeri 1 Balaesang pada Mata Pelajaran Fisika. Jurnal Pendidikan Fisika Tadulako (JPFT), 6(3), 40-44.

Nana. (2018). Penerapan Model Creative Problem Solving Berbasis Blog Sebagai Inovasi Pembelajaran di Sekolah Menengah Atas dalam Pembelajaran Fisika. Prosiding Seminar Nasional Fisika dan Aplikasinya, 190-195.

Nana \& Surahman, E. (2019). Pengembangan Inovasi Pembelajaran Digital Menggunakan Model Blended POE2WE di Era Revolusi Industri 4.0. Prosiding SNFA (Seminar Nasional Fisika Dan Aplikasinya), 82-90.

Saputra, H. N. (2019). Analisis Respon Guru dan Siswa Terhadap Penerapan Model Siklus Belajar Hipotesis Deduktif. Jurnal Pedagogik, 6(2), 278-299.

Sari, S. N., Supriyanti, F. T., \& Dwiyanti, G. (2019). Analisis Keterampilan Proses Sains pembelajaran Larutan Penyangga Menggunakan Siklus Belajar Hipotesis Deduktif. EduChemia (Jurnal Kimia dan Pendidikan), 4(1), 77-88.

Sudana, I. M. (2020). Meningkatkan Aktifitas Dan Hasil Belajar Fisika Melalui Penerapan Model Pembelajaran Siklus Belajar Hipotetik-Deduktif. Indonesian Journal of Educational Development, 1(1), 112-121.

Sugara, Y.D., Supoto, \& Latifah, E. (2016). Kesulitan Siswa SMA dalam Memahami Gerak Harmonik Sederhana. Pros. Semnas Pend. IPA Pascasarjan UM. 1, 506-512.

Parnafes, O. (2010). When Simple Harmonic Motion is not That Simple: Managing Epistemological Complexity by Using Computer-based Representations. Journal of Science Education and Technology. 19, 565-579. 